\title{
Politik och fantasi i svensk reproduktionspolitik
}

\section{Af Helena Tinnerholm Ljungberg}

\begin{abstract}
Politics and Fantasies in Swedish Human Reproduction Policy

In March 2012 the Swedish parliament asked the government to draft a law that will allow single women access to in-vitro fertilization and donor insemination. The decision represents a partial dissolution of the long-standing assumption in Swedish politics that two parents are necessary to provide what is 'in the child's best interest'. This article comprises a psychoanalytically informed discourse analysis of the construction of the single mother in this policy area. It is argued that the inclusion of single women was made possible by a redrawing of the boundary between 'good' and 'bad' mothers so as to displace the characteristics that previously disqualified the entire group of single women from motherhood to a particular subset of the group: those who do not make their babies in the 'right' way or with the 'right' intentions. The 'good' single mother, on the other hand, is framed along the lines of (hetero)repronormativity: she is expected to desire a man in her life, as well as harboring a wish to provide her children with male role-models and a right to know who the sperm donor is.
\end{abstract}

\section{KEYWORDS}

Assisted reproduction, single mothers, heteronormativity, psychoanalysis, state policy

Helena Tinnerholm Ljungberg er ph.d.-studerende og underviser i statskundskab ved Stockholms Universitet. Hendes ph.d.-projekt omhandler svensk reproduktionspolitik i et poststrukturalistisk og psykoanalytisk perspektiv. 


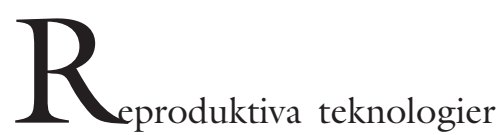

bär på möjligheten att störa, utmana och rubba rådande legala och normativa ordningar och hur vi ser på familjer, föräldraskap och reproduktion. Fertilitetsbehandlingar som insemination, befruktning utanför kroppen och donation av ägg och spermier skulle kunna förändra den förgivettagna synen på släktskapet mellan barn och föräldrar (jfr Graham 2012). Detta faktum har givit upphov till ett fält av reproduktionspolitik där dessa element ständigt förhandlas.

I Sverige har reproduktionspolitiken i allmänhet - och politiken kring assisterad befruktning i synnerhet - brottats med frågor som till exempel vilka tekniker som ska tillåtas och vilka som ska få tillgång till dessa. Mer specifikt har reproduktionspolitiken diskuterat insemination, provrörsbefruktning och donation av spermier och ägg. I dagsläget är alla dessa tekniker tillåtna i lag i Sverige, men bara under vissa förutsättningar. När lagen om insemination trädde $\mathrm{i}$ kraft 1985 begränsades vilka som kunde bli föräldrar uttryckligen till heterosexuella gifta eller sammanboende par. Denna begränsning kvarstod när lagen om befruktning utanför kroppen stiftades år 1988. År 2005 fick lesbiska par rätt till assisterad befruktning. Även i diskussioner kring inkluderandet av lesbiska par framhölls vikten av tvåsamhet och ett grundläggande antagande var "... att ett barn som har kommit till med hjälp av assisterad befruktning skall ha två föräldrar och att barnet skall ha fötts av en av föräldrarna" (prop. 2004/05:137: $39)$.

En utgångspunkt för den svenska lagstiftningen har således varit tvåsamhet. För att få tillgång till fertilitetsbehandling inom ramarna för svensk sjukvård krävs $\mathrm{i}$ nuläget två blivande föräldrar. Ensamstående kvinnor har däremot inte haft tillgång till assisterad befruktning. Den svenska lagstiftningen begränsar också vissa andra kombinationer av tekniker. Till exempel måste minst en genetisk länk förekomma mellan det blivande barnet och föräldrarna. Det innebär att det inte är möjligt att ta emot både ägg och spermier inför en provrörsbefruktning. Inte heller är det möjligt att ta emot ett redan befruktat ägg (SMER 2013:1: 57). Barn som har kommit till med hjälp av donerade könsceller har rätt att få information om givaren när barnet $\mathrm{i}$ fråga "uppnått tillräcklig mognad" (bet. 2011/12:SoU26: 10). Tidigare forskning har visat att rätten till ursprunget har varit en central aspekt av svensk reglering av assisterad befruktning (Jonsson Malm 2011).

Även andra aspekter av den svenska lagstiftningen kring assisterad befruktning har varit föremål för tidigare forskning. Exkluderandet av homosexuella eller ensamstående kvinnor har karaktäriserats av Liljestrand (1995: 290) som ett "andra klassens medborgarskap" (min översättning). Carbin, Harjunen och Kvist (2011) menar att efter de lagförändringar som inkluderade homosexuella kvinnliga par förekommer inte längre ett lika starkt skillnadsgörande mellan kvinnor baserat på sexualitet i Sverige. Däremot kvarstår uteslutningen av ensamstående kvinnor (Ibid: 75). Författarna konstaterar att det framför allt är betoningen av tvåsamhet som gjort det möjligt att exkludera ensamstående kvinnor i den svenska reproduktionspolitiken (Ibid: 76). Tvåsamhet $\mathrm{i}$ bredare bemärkelse har också analyserats i svensk forskning, bland annat i relation till äktenskapet (Andersson 2011) och som en aspekt av hur begreppet barnets bästa laddats med olika innehåll vid olika tidpunkter (Lindgren 2006).

En av de senare årens större händelser på området är riksdagsbeslutet från 2012 om att ensamstående kvinnor ska få rätt till assisterad befruktning (riksd. prot. 2011/ 12:91). Beslutet innebär att regeringen ska återkomma till riksdagen med ett lagförslag som ska reglera ensamstående kvinnors till- 
gång till assisterad befruktning. Det empiriska material som analyseras $\mathrm{i}$ den här artikeln är riksdagsdebatten som föregick det nämnda beslutet, socialutskottets betänkande Assisterad befruktning (bet. 2011/ 12:SoU26), samt de 11 motioner som rörde inkluderingen av ensamstående som socialutskottet diskuterade i betänkandet. ${ }^{1}$ Förutom nämnda riksdagstryck analyseras även statens medicinsk-etiska råds (hädanefter SMER) rapport Assisterad befruktning - etiska aspekter som presenterades under våren 2013.2 I rapporten diskuterades bland annat de aspekter av reproduktionspolitiken som SMER anser kommer att påverkas av beslutet.

Den här artikelns syfte är att analysera dels hur ensamstående mödrar framställdes i den politiska debatt som föregick riksdagsbeslutet, dels vilka konsekvenser som skrivs fram av SMER i och med att tvåsamhet inte längre anses vara ett grundläggande krav vid assisterad befruktning.

\section{(HETERO)REPRONORMATIVITET}

För att analysera den svenska reproduktionspolitiken använder jag mig av begreppet (betero)repronormativitet. Det inbegriper ett dubbelt perspektiv där heteronormativitet och reproduktionsnormer står i fokus. Katherine M. Franke (2001) har använt begreppet repronormativitet för att teoretisera och kritisera följderna av antagandet att de flesta kvinnor blir mödrar. Hon jämför begreppet med heteronormativitet som används för att kritisera de utgångspunkter som följer antagandet att de flesta kvinnor är heterosexuella. Repronormativitet har dock inte fătt samma teoretiska uppmärksamhet. Franke menar att: "repronormativity remains in the closet even while heteronormativity has stepped more into the light of the theoretical and political day" (Franke 2001: 185). Franke hävdar att det framförallt är heterosexuellas kvinnors beslut att inte bli föräldrar och homosexuella kvinnors beslut att bli föräldrar som ses som aktiva val, motsatserna tas däremot för givna (Ibid: 185-186). På ett liknande sätt har Judith Halberstam beskrivit hur "reproheterosexualiteten" kan förstås som en ideologi som “försöker ge stöd åt 'riktigheten' i våra former av samhällsorganisationer" när dessa utsätts för utmaningar (Halberstam 2007: 10.)

Genom att betona (hetero)repronomativitet möjliggörs ett kritiskt perspektiv på de normer som omgärdar familjen där föräldrarnas relation är tvåsam, olikkönad, präglad av kärlek, intimitet och sexualitet, och där de är i rätt ålder (jfr Cutas och Chan 2012, jfr Graham 2012). Vidare öppnas en möjlighet till en viss distans till förgivettagandet om att alla vill reproducera sig (jfr Engwall och Peterson 2010) och att de vill göra det på samma sätt.

\section{METOD}

Tidigare studier av den svenska reproduktionspolitiken har inriktat sig främst på den semiotiska eller språkliga nivån, det vill säga på den diskursiva konstruktionen av mening kring familjebildning, barnalstrande, den medicinsk-teknologiska utvecklingen och politikens roll i regleringen av hela detta komplex (se till exempel Carbin, Harjunen och Kvist 2011; Jonsson Malm 2011, Nordqvist 2006). Ett undantag i sammanhanget är historikern Sara Edenheims (2005) avhandling som berör ämnet reproduktion ur ett psykoanalytiskt perspektiv.

Även i den här artikeln är utgångspunkten diskursanalytisk, närmare bestämt utgår den från politisk diskursteori (PDT). Det är den gren av diskursanalys som följer i spåren av Ernesto Laclaus och Chantal Mouffes arbeten (Glynos et al. 2009). Detta perspektiv kompletteras av en psykoanalytisk ingång så som den utvecklats av bland andra Yannis Stavrakakis (1999; 2007), Slavoj Žižek (2001), samt Jason Glynos och David Howarth (2007). Sammantaget möjliggör dessa två perspektiv en bredare ingång till diskursivt meningsskapande kring 
reproduktion i den offentliga politiken, där också den affektiva nivån kan analyseras.

Med begreppet diskurs avses här ett kulturellt och historiskt specifikt system av meningsfulla praktiker som "etablerar ett system av relationer mellan olika objekt och praktiker" (Howarth och Stavrakakis 2000, s. 3; se Howarth 2000). Diskurser formas genom artikulatoriska processer, där objekt och subjekt får sin innebörd genom att tillskrivas mening i relation till varandra. Tillkomsten och förändringen av diskursiva formationer kan analytiskt beskrivas på flera sätt. Jag har här valt att följa Glynos och Howarths (2007) "logikansats" där samhälleliga processer kategoriseras i termer av sociala, politiska, och fantasmatiska logiker. Logikerna kommer att användas för att kategorisera de problemframställningar som görs i politiken.

Sociala logiker syftar här på de processer av meningsskapande som följer etablerade och icke-ifrågasatta sociala regler och institutionaliserade mönster (Glynos och Howarth 2007: 154). Min analys inriktas i detta avseende på att belysa de normaliserande och naturaliserande antaganden som ligger till grund för olika aktörers utsagor och handlingar.

Politiska logiker handlar om olika försök att utmana eller försvara den rådande ordningen - det vill säga att politisera eller avpolitisera en given samhällsordning eller någon aspekt av den (Ibid: 154). Politiserandet kan ske genom att man ifrågasätter det förgivettagna, väcker nya frågor, driver på eller bromsar förändringar. Detta sker genom att enskilda fenomen ekvivaleras med andra praktiker (eller subjekt) eller differentieras från dessa (Ibid: 144). Som jag kommer att visa nedan likställs vissa ensamstående mödrar med de som redan har tillgång till assisterad befruktning av dem som förespråkar en utvidgning av lagstiftningen. Bland de som motsätter sig inkluderingen betonas istället skillnader mellan de ensamstående och de redan inkluderade föräldrasubjekten.
Genom att studera fantasmatiska logiker är avsikten att fånga den kraft som de meningskapande operationerna (de sociala och politiska logikerna) utövar över diskursens subjekt genom att känslomässigt binda dem till en viss världsbild (Laclau 2005: 101; Glynos och Howarth 2007: 145). Det är i detta moment som den psykoanalytiska teorin blir relevant genom att belysa den komplexa dialektik av brist, begär och fantasi som underbygger och stabiliserar diskursiva formationer. Den psykoanalytiska utgångspunkten koncentreras här till begreppet ideologisk fantasi. Kortfattat kan detta beskrivas som de försök att täcka över luckor och hål i diskurser, eller med Slavoj Žižeks ord den "skärm" som täcker över den fundamentala omöjligheten i det sociala. Med det socialas omöjlighet menas att samhället aldrig kan konstitueras fullt ut, bli färdigt eller lappa över alla sprickor. Istället för att konfronteras med det socialas inneboende omöjlighet erbjuder fantasin en annan utväg - sprickor förklaras genom hänvisningar till ett tillfälligt hinder, eller till en fientligt sinnad kraft (Žižek 2001: 146). Det fantasmatiska kan till exempel ta sig uttryck i en fasanfull dimension, som "förutspår en katastrof om ett hinder visar sig vara oöverstigligt” (Glynos och Howarth 2007: 145, min översättning). I materialet har jag också letat efter de fall där de omtalade subjekten făr sina motiv misstänkliggjorda.

\section{PROBLEMFRAMSTÄLLNINGAR I DEN POLITISKA DEBATTEN}

I sin diskussion av frågan anser Socialutskottet att den rådande exkluderingen av ensamstående kvinnor är problematisk (bet. 2011/12:SoU26: 13). Mer specifikt ställer sig utskottet kritiskt till att rådande lagstiftning gör skillnad mellan adoption och assisterad befruktning, där ensamstående kvinnor har möjlighet till adoption men inte insemination. Jämförelser mellan adoption och insemination har även tidigare varit 
vanligt förekommande vid regleringar av assisterad befruktning (se Liljestrand 1995: 279-280, Jonsson Malm 2011). Utskottet konstaterar vidare att "familjer kan se olika ut" och att det redan finns barn till ensamstående som kommit till "på andra sätt än genom assisterad befruktning inom svensk sjukvård" (bet. 2011/12:SoU26: 13). Ett annat tillvägagångssätt är assisterad befruktning utomlands (där reglerna för barnets rätt till sitt ursprung inte ser ut på samma sätt som i Sverige). En sådan situation anses inte önskvärd (se exempelvis mot. 2011/12:C391 (FP)).

SMER diskuterar också ensamstående kvinnor i sin rapport, och menar att det uppstår problem om insemination eller provrörsbefruktning för ensamstående är olagligt i Sverige men lagligt utomlands, då detta kan leda till att de som vill ha barn söker sig utomlands. Detta kan i sin tur leda till följdproblem som "medicinsk och social osäkerhet” och att det "i vissa länder tillämpas återföring av flera ägg vilket kan resultera i en riskfylld multipel graviditet" (SMER 2013:1: 101). Här skrivs också fram att barnets vetskap om sitt ursprung inte kan garanteras och en övergripande frågeställning presenteras: "Hur viktigt är det för barnet att ha två föräldrar?" (Ibid: 102). För läkare och det omgivande samhället kan detta också leda till svårigheter, anser SMER: ska läkarna exempelvis vara behjälpliga i förberedelserna inför behandlingar utomlands?

SMER lyfter vidare upp vissa aspekter som de menar bör övervägas vid en närmare reglering av ensamstående och assisterad befruktning. SMER:s nya förslag går ut på att "en bedömning med beaktande av det blivande barnets bästa [bör äga rum] vid alla former av assisterad befruktning" (Ibid: 219). Ett av de främsta skälen för att ändra den nuvarande ordningen sägs vara att även om man genomför befruktning med egna könsceller är det numera - som en följd av att spermier och ägg (inklusive befruktade ägg) kan frysas ner och implanteras efter en längre tid - tekniskt möjligt att skjuta upp befruktningen till högre åldrar. Enligt SMER bör en grundläggande princip vara att det ska finnas minst en förälder som kan förväntas leva tills barnet uppnår vuxen ålder (Ibid: 201).

En förändring som ligger i linje med den svenska riksdagens beslut, enligt SMER, är frågan om det bör vara möjligt att använda sig av könsceller som donerats även om donatorn skulle avlida under processens gång. Detta eftersom man på grund av riksdagsbeslutet kan "anse att det inte föreligger någon avgörande skillnad $\mathrm{i}$ att barnet har en eller två föräldrar vid tillkomsten." (Ibid: 187)

En annan förändring är en vidare definition av begreppet 'ofrivilligt barnlös'. Den definition som SMER i sin rapport utgår ifrån innefattar "samtliga par eller personer som av olika anledningar är ofrivilligt barnlösa med eller utan en medicinsk infertilitet" (Ibid: 39). De förhåller sig också till tidigare definitioner av begreppet:

Ofrivilligt barnlös är en person eller ett par som inte kan få barn och vill ha barn, oavsett orsak till barnlösheten. Tidigare användes ofta begreppet ofrivillig barnlöshet synonymt med medicinsk infertilitet. Idag talar man om ofrivillig barnlöshet i vidare bemärkelse. (SMER 2013:1: 200)

Som exempel på grupper där barnlösheten inte handlar om medicinska problem nämns "homosexuella par", "transgender-par eller personer", "ensamstående", "par som av olika skäl har svårigheter att genomföra samlag” och “asexuella” (Ibid: 40). Utifrån en (hetero)repronormativ kritisk läsning av de olika kategorierna är det värt att uppmärksamma hur samlaget nämns i den här indelningen. Jag kommer att återkomma till hur vi kan läsa "svårigheter att genomföra samlag” här nedan. 


\section{SOCIALA LOGIKER}

I det här avsnittet kommer jag att ge två exempel som visar på den ram inom vilken de olika politiska kraven måste befinna sig för att bli rimliga utsagor.

En första social logik handlar om en strävan efter överensstämmelse mellan de familjer som finns i praktiken och de familjer som konstitueras genom politisk reglering. Här betonas hur familjer som utgörs av ensamstående kvinnor och barn redan existerar och kontinuerligt bildas (exempelvis mot. 2011/12:So521 (S)). I den här logiken är det centrala att dessa familjer faktiskt redan finns och kan komma till på andra sätt än genom assisterad befruktning inom ramarna för svensk lagstiftning och svensk sjukvård.

Den traditionella kärnfamiljen som består av mamma, pappa, barn är i dag en gammaldags norm där många existerande familjebildningar inte får plats. Mångfalden av familjeformer har ökat, och det är rimligt att lagstiftningen anpassar sig efter hur människor faktiskt lever. (mot. 2011/ 12:So462 (V))

Begreppet familj har också vidgats genom åren från att ha varit en traditionell kärnfamilj med mamma, pappa och barn till att numera innefatta homosexuella relationer och ensamstående hushåll. Denna utveckling är viktig, välkomnad och kort sagt en prägel av det moderna samhälle vi lever i. (mot. 2011/12:

So248 (S))

Denna logik återfinns också hos SMER som menar att en övergripande utgångspunkt som styrt deras arbete med reproduktionspolitiska frågor är att $\mathrm{i}$ en etisk analys ska "lika $[\ldots]$ behandlas lika, om det inte finns relevanta skillnader" (SMER 2013:1: 108).

En andra social logik handlar om att $r e^{-}$ produktionspolitiken ska vara rätt $i$ tiden. Utskottet skriver således att “... tiden nu $\ddot{a r}$ mogen att jämställa par och ensamstående när det gäller rätten till behandling med as- sisterad befruktning" (bet. 2011/12: SoU26: 1, min kursivering). Liknande formuleringar förekommer hos riksdagsledamöterna. De beskriver Sverige som i "framkant när det gäller familjepolitiska frågor", men samtidigt beskrivs hur "Sverige behöver en mer modern lagstiftning" och hur "[d]et är hög tid att Sverige tar sitt ansvar" (mot. 2011/12:So472 (S)). Andra utsagor handlar om hur problemet inte längre bör förhalas och att "[f]rågan om ensamstående kvinnors rätt att insemineras är vidare en bedrövlig följetong" (mot. 2010/11:Sfl3 (MP)) och att det nu är "hög tid" att inkludera ensamstående (mot. 2011/12: So242 (MP) och riksd. prot. 2011/12:91, Anf. 8, Agneta Luttropp (MP)). Att ensamstående inte är inkluderade beskrivs vidare som "otidsenligt" (riksd. prot. 2011/ 12:91, Anf. 21 Mats Gerdau (M)).

Också de som motsätter sig att ensamstående ska fă rätt till fertilitetsbehandling ger sina förslag en temporal dimension. Detta sker för det första med hänvisning till att vara "modern" men här i en annan betydelse: en inkludering av ensamstående skulle stå i motsatsförhållande till "dagens moderna lagstiftning där papparollen betonas" (bet. 2011/12:SoU26, särskilt yttrande 1, Anders Andersson (KD)). För det andra betonas av motståndarna att Sverige "under lång tid haft som utgångspunkt att barnets rätt till två föräldrar ska värnas" (bet. 2011/12:SoU26, särskilt yttrande 1, Anders Andersson KD). Även pappans roll sätts in i en historisk ram, där generationernas gång och betydelse för framtiden skrivs fram: "vi tror att pappan är viktig. Vi menar att det som har fört vårt samhälle framåt $\mathrm{i}$ generationer också bör fortsätta att göra det."(riksd. prot. 2011/12:91, Anf. 77 Roland Utbult $(\mathrm{KD}))$. Vidare på samma tema heter det att det är möjligt att både framhålla "familjen, såsom vi levt i generationer, som en bra modell" och samtidigt visa respekt för andra familjeformer (riksd. prot. 2011/12:91, Anf. 81 Roland Utbult $(\mathrm{KD}))$. 
Både förespråkare och motståndare till inkluderingen av ensamstående förhåller sig till en konstruktion av Sverige i termer av modernitet, framtid och progression (jfr Lüttichau 2004). De som förespråkar en inkluderande förändring framställer detta beslut rätt i tiden och i linje med en framtid som kommer att komma. Hos de som vill bevara den rådande ordningen är det snarare generationernas gång som anses leda till en bra framtid.

Som historikern Sara Edenheim påpekat förekommer en föreställning i den offentliga politiken som innebär att det finns ett slags rätt tid att vara $i$, vilket $i$ sin tur innebär att det är "det progressiva juridiska systemets plikt att se till att det är 'i synk med sin tid' och att 'ställa allt till rätta'” (Edenheim 2010: 38, min översättning).

Ett liknande exempel från det material som studerats här kommer till uttryck i riksdagsdebatten där en socialdemokrat riktar kritik mot motståndare till inkluderingsförslaget och säger att eftersom Kristdemokraterna även i tidigare debatter motsatt sig förändringar (som exempel nämns regleringarna av assisterad befruktning för lesbiska par) visar detta sammantaget "att man alltid får dra KD in i framtiden när det gäller familjepolitiken. Det får vi göra även den här gången." (riksd. prot. 2011/ 12:91, Anf. 83 Börje Vestlund (S)).

Edenheim problematiserar denna tidslogik, i hennes fall i statligt material om diskriminering, och menar att den där tar sig uttryck som att “ingenting som är 'i tid' kan vara dåligt, samtidigt som allt som är 'ur led' inte bara är dåligt utan oförmöget, enligt den här logiken, att omfatta något annat än dåtid.” (Edenheim 2010: 39, min översättning)

\section{POLITISKA LOGIKER}

Om de sociala logikerna handlar om att ge en bild av de ramar inom vilka olika krav kan situeras, så handlar de politiska logikerna snarare om de gränsdragningar som sker inom dessa ramar. Kort kan de beskrivas som "konstruktionen, försvaret och naturaliseringen av nya gränser" (Glynos och Howarth 2007: 141, min översättning).

I och med förslaget att inkludera ensamstående kvinnor utökas den grupp som har tillgång till assisterad befruktning med ytterligare en kategori. Ensamstående kvinnor jämförs med dem som redan är inkluderade (se mot. 2011/12:So481 (MP)), och artikuleras i linje med andra ensamstående som skaffar barn genom till exempel adoption (se mot. 2011/12:So242 (MP); mot 2011/12:So462 (V); mot. 2011/ 12So592 (S); mot. 2011/12:So596 (S)). I en motion relateras frågan även till att det $\mathrm{i}$ vissa landsting helt saknas åldersgränser för de män i parrelationer som kan fă hjälp genom assisterad befruktning, och motionären ifrågasätter: "På vilket sätt detta skulle vara bättre för ett barn än att från början ha en ensamstående mamma..." (mot. 2011/ 12:So248 (S)).

Kritikerna till inkluderingsförslaget invänder dels genom att förespråka behovet av två föräldrar, dels genom att understryka att hur bra den ensamstående mamman än är så finns det något med fadern som inte kan ersättas av en ensam moder (bet. 2011/12:SoU26, särskilt yttrande 1, Anders Andersson (KD)) - detta oavsett om barnet är planerat och efterlängtat. Vidare jämförs svensk lagstiftning med andra länders lagstiftning och den förra beskrivs som "långtgående när det gäller att säkerställa att barn får två föräldrar, och stor vikt har lagts vid att barn får både en mor och en far" (bet. 2011/12:SoU26, Särskilt yttrande 1, Anders Andersson (KD)). Fadern skrivs fram som viktig och det betonas hur "svensk lagstiftning bygger på att pappor har ansvar för sina barn" (bet. 2011/ 12:SoU26, reservation 1 Anders Andersson (KD) och Per Ramhorn (SD)).

Parallellt med detta ekvivalerande sker ett uteslutande, en gränsdragning mellan det bra och goda som kan inkluderas och det mindre bra som måste hållas borta. 
Detta sker genom att en gräns dras upp mellan de goda ensamstående mödrarna och de andra ensamstående mödrarna, ett längre citat får utgöra ett exempel här:

Det hårda motståndet mot att tillåta insemination av ensamstående kvinnor har också bottnat i den egentliga åsikten att barn till ensamstående kvinnor har det svårt. [...] Ensamstående mammor lever oftare än andra med små ekonomiska marginaler men har oftast möjligheter att kompensera det genom kärlek. Den här stora gruppen, som vi ser i dag i Sverige, med ensamstående mammor har mycket lite eller rent av ingenting [sic] med den grupp som dagens diskussion rör. De kvinnor som är ensamstående och vill ha barn genom insemination är oftast i övre medelåldern. De har oftast ett gott socialt kontaktnät och oftast välordnade ekonomiska förhållanden. (riksd. prot. 2011/12:91, Anf. 27, Anders W Jonsson (C))

Hos de som förespråkar en utvidgad inseminationspraktik är det viktigt att visa att ensamstående mammor som skaffar barn genom insemination inte har de egenskaper som tillskrivs andra ensamstående mammor. Här framhålls hur de barn som kommer till via insemination är "planerade" och "efterlängtade" barn (mot. 2011/12: So592 (S)) och att de kvinnor som skaffar barn är "ansvarsfulla" (riksd. prot. 2011/12:91, Anf. 21 Mats Gerdau (M)). Ytterligare en utgångspunkt i politiken är att svensk inseminationslagstiftning och praktik är bättre än den som finns utomlands. Den förstnämnda skrivs dels fram som säkrare, dels som önskvärd för att barnet i Sverige får rätt till kännedom om sitt ursprung, något som inte alltid är fallet utomlands (bet. 2011/12:SoU26: 13) .

När SMER publicerar sin rapport har riksdagen redan fattat sitt beslut. SMER:s diskussioner om ensamstående mödrar och assisterad befruktning koncentreras således till de etiska aspekter som de anser bör finnas med i förberedelserna till en ny lagstift- ning. SMER diskuterar bland annat vilka metoder som bör vara tillgängliga för ensamstående; att det bör övervägas “om spermiedonatorerna bör ges särskild möjlighet att samtycka till donation till ensamstående kvinnor" (SMER 2013:1: 211). Vidare tas det upp att ensamstående kvinnor bör omfattas av en bedömning innan assisterad befruktning kan bli aktuell där det ska tas i beaktande hur kvinnornas "sociala nätverk" ser ut (Ibid: 211). Rådet problematiserar också att inkluderingen kan komma att "påverka donationsviljan" (Ibid: 218) och deras förslag att donatorerna ska kunna välja att inte donera till ensamstående kvinnor avviker i relation till nuvarande lagstiftning. De motiverar förslaget med att "frånvaron av en social och rättslig far kan medföra ett större intresse hos barnet att söka upp donatorn" (Ibid: 218). Betydelsen av något slags fadersfigur framträder i dessa uttalanden, parallellt med vad som framstår som en vilja att ge donatorn möjlighet att göra skillnad mellan olika mottagare.

SMER beskriver forskningsläget som att barn till ensamstående löper vissa risker för "känslomässiga och beteendemässiga problem", men menar samtidigt att det är "svårt att avgöra om de ökade problemen [...] beror på själva avsaknaden av en far eller på andra faktorer" (Ibid: 213). Men SMER diskuterar även annan forskning som visat på goda resultat för de ensamstående mödrarna och deras barn och beskriver de självvalt ensamstående mödrarna som att de genomgår assisterad befruktning eftersom "de inte längre kan (pga. ålder) eller inte vill vänta på den rätte partnern. Dessa kvinnor är i regel välutbildade, med god ekonomi och de har ett stödjande socialt nätverk." (Ibid: 214-215)

\section{FANTASMATISKA LOGIKER}

Det skillnadsgörande som SMER gör mellan de självvalt ensamstående och de andra som jag visade på ovan kommer också till uttryck i den politiska diskussionen i form 
av ett misstänkliggörande av vilka motiv och intentioner som ensamstående mödrar kan tänkas ha. De två fantasmatiska logiker som diskuteras i det här avsnittet kommer att handla om just detta.

I en första fantasmatisk logik betonas hur ensamstående kvinnor redan skaffar barn, antingen utomlands eller genom "tillfälliga förbindelser", och att detta motiveras av barnlängtan som en "naturlig drivkraft" (riksd. prot. 2011/12:91, Anf. 21 Mats Gerdau (M)). Den här uppfattningen motiverar slutsatsen att om ensamstående kvinnor skaffar barn är det bättre att de gör det inom ramen för svensk sjukvård och reproduktionslagstiftning:

Ensamstående kvinnor med barnlängtan har i alla tider funnit vägar att skaffa sig barn. Det kan vara genom en destruktiv relation (hellre än ingen relation alls som skulle medföra barnlöshet) eller att "råka bli gravid" efter en krogkväll eller på utlandssemestern. Detta kan dock innebära flera problem: Kvinnan utsätter sig för risk för könssjukdomar; en man som inte valt att bli pappa blir det [sic]. Dessutom medför det svårigheter att vara helt ärlig inför barnet och omgivningen. Att få barn genom donatorinsemination är, utan att moralisera över andras val, ett bättre och säkrare alternativ för ensamstående. (mot. 2011/12:So596 $(\mathrm{S})$ ).

Jag tror att alla vet att det har funnits många andra sätt för många kvinnor att skaffa barn som är betydligt sämre än insemination om man inte väljer dem frivilligt. Man har gjort det på semestern. Barnet har inte vetat vem fadern är, och pappan har inte vetat om att han har blivit pappa. (riksd. prot. 2011/ 12:91, Anf. 10, Eva Olofsson (V)).

... eller försöka hitta en lämplig man någonstans som, med eller mot sin vilja, kan ställa upp och bli pappa. Det kanske inte känns rätt, vare sig mot barnet eller mot mannen. (riksd. prot. 2011/12:91, Anf. 21 Mats Gerdau (M)).
När deras barnlängtan blir för stark återstår att låta sig insemineras på klinik utomlands. (mot. 2011/12:So667 (M)).

I de ovanstående citaten ser vi exempel på hur insemination artikuleras i relation till andra sätt för ensamstående kvinnor att skaffa barn på. Här framställs insemination genomgående som ett "bättre" och "säkrare" alternativ. Ett liknande resonemang förekom även i en statlig utredning från 1953, men där handlade det istället om risker för att heterosexuella kvinnor i "sterila relationer" (SOU 1953:9: 35) skulle göra barn genom "utomäktenskapligt könsumgänge" (Ibid: 36).

En andra fantasmatisk logik kan betecknas som ett 'skräckscenario' som handlar om att ensamståendes möjligheter till insemination skulle kunna leda till en värld utan manliga förebilder eller en där fadern skulle få en minskad betydelse. De som motsätter sig inkluderingen menar att de inte vill "medverka till en opinionsbildning som reducerar pappans roll och betydelse $\mathrm{i}$ barnens liv." (riksd. prot. 2011/12:91, Anf. 11 Anders Andersson (KD)).

Även de som vill inkludera ensamstående förhåller sig till och skriver fram betydelsen av det manliga och faderskapet, om än i andra former än som en nödvändig social förälder. Här understryks vikten av att dessa barn inte "lever ett liv där det saknas manliga förebilder" (riksd. prot. 2011/12:91, Anf. 20, Christin Hagberg (S)). Detta sker genom att avfärda att insemination för ensamstående hotar betydelsen av det manliga eller genom att skriva fram att den tvåsamma familjeformen fortfarande är den mest önskvärda - även för de ensamstående kvinnorna själva:

När det gäller könsidentitet är det viktigt att också ha män i sitt liv. Det är många av de här barnen som har en bror till mamman, en god vän, en morfar eller en farfar som betyder väldigt mycket för dem. Det är inte så att man lever i en värld av enbart kvinnor. (riksd. prot. 
2011/12:91, Anf. 12, Eva Olofsson (V), min kursivering)

Jag tror inte att rätten till insemination för ensamstående föräldrar kommer att innebära en explosion där pappor inte spelar någon roll."(riksd. prot. 2011/12:91, Anf. 14, Eva Olofsson (V))

Kvinnorna utesluter inte heller en framtida relation med en man. (SMER 2013:1: 215.)

Jag läste nyligen om en annan kvinna som faktiskt först skaffade sig barnet, sedan hittade hon mannen som kommer att vara pappan i det här barnets liv. (riksd. prot. 2011/12:91, Anf. 12, Eva Olofsson (V))

Att tillgång till assisterad befruktning för ensamstående och homosexuella kvinnor upplevs som hotande mot män eller manlighet har också framkommit i andra studier. I en australisk studie beskrevs hotet i det empiriska materialet bland annat som ett "post-feministiskt samhälle" (Correia och Broderick 2009: 247). De olika resonemangen förhåller sig till en fasansfull föreställning om att insemination för ensamstående skulle kunna leda till en värld där män saknar reproduktiv eller samhällelig betydelse. En studie som undersökt hur ensamstående heterosexuella mödrar som fått barn som singlar och genom assisterad befruktning beskriver hur de själva framställer sina överväganden både som en längtan efter en kärnfamilj samtidigt som de positionerar sig mot andra ensamstående mödrar (Graham 2012). En konsekvens av en uppdelning mellan 'bra' och 'dåliga' mödrar kan vara att gemensamma politiska krav som inte ligger i linje med den dominerande synen på reproduktionspolitik omöjliggörs.

Det (heterosexuella, reproduktiva, penetrerande) samlagets betydelse är således ambivalent, vilket också kan utläsas ur SMER:s rapport när de listar de kategorier som berörs av ofrivillig barnlöshet. I rapporten räknades bland annat asexuella och de som har "svårigheter att genomföra samlag" upp (SMER 2013:1: 40). Ett sätt att tolka detta uttalande kan vara att den utvidgade beskrivningen av barnlöshet inte inkluderar dem som inte vill genomföra ett (penetrerande) samlag. I min tolkning blir detta till ett rangordnande av sätt på vilket en kan bli med barn, där det eftersträvandsvärda är samlaget och där assisterad befruktning blir en reservlösning. Således måste de ensamstående kvinnorna, för att kunna inkluderas, artikuleras som att de inte hyser sådana önskemål - snarare framställs insemination som en sista utväg och inte som ett positivt laddat val.

Gemensamt för de bägge fantasmatiska logikerna är att ensamstående kvinnors reproduktion genom assisterad befruktning inte framställs som ett hot mot den rådande sociala ordningen, snarare skrivs det fram som en praktik som löser några av de problem som andra former för reproduktion blir bärare av.

\section{SLUTDISKUSSION}

När ensamstående kvinnor inte längre exkluderas med hänvisning till att de saknar en central komponent (tvåsamhet, helst i kombination med en man) ekvivaleras de med andra som redan har tillgång till assisterad befruktning. Mest vanligt är att insemination jämförs med adoption (jfr Jonsson Malm 2011). Det framstår som viktigt att skriva fram att de kan ge barnet trygghet, manliga förebilder, ett socialt nätverk, samt möjliggöra att barnet får tillgång till sitt ursprung. Det senare inkluderar även artikuleringar om varför det är bättre att barnen kommer till inom den svenska sjukvården hellre än genom tillfälliga förbindelser eller genom inseminationer i hemmet eller utomlands. Att barn redan kommer till genom assisterad befruktning utomlands fungerar som motivering både på så sätt att dessa familjer redan finns till, vilket är i linje med logiken att lagstiftning- 
en bör återspegla faktiska förhållanden och praktiker, och som bakgrund till en politisk vilja att reglera den reproduktion som förekommer. I samma anda finns en strävan att hålla reproduktionen inom nationens gränser och innanför de lagar och regleringar som gäller i Sverige.

När det nu finns en politisk vilja till inkludering delas gruppen ensamma mödrar upp i två grupper, de som vill skaffa barn inom ramarna för svensk lagstiftning och sjukvård och 'de andra'. Samtidigt förskjuts de egenskaper som ensamma mammor tidigare antagits ha som grupp till 'de andra':

'BRA' ENSAMSTÅENDE MAMMOR: mogna/lagom gamla ansvarsfulla planerar sina barn skulle välja insemination inom den svenska sjukvården om det var ett alternativ Välutbildade $=$ ordnad ekonomi stort socialt nätverk ger sina barn manliga förebilder låter barnet ta del av sitt ursprung skulle vilja ha en närvarande pappa.

'DÅLIGA' ENSAMSTÅENDE MAMMOR: omogna/unga/allt för gamla skaffar barn lättvindigt/genom tillfälliga förbindelser dålig ekonomi riskerar könssjukdomar gör en man till far utan att han har något att säga till $\mathrm{om} /$ får veta något.

Med utgångspunkt i det (hetero)repronormativa perspektivet blir det tydligt hur 'de andra' får ta över rollen av att vara de som inte vill ge sitt barn manliga förebilder och rätten till sitt ursprung. Eller så identifieras de som kvinnor som skaffar barn oplanerat eller på 'fel sätt', för tidigt eller under osäkra ekonomiska förhållanden. I artikeln har jag bara kunnat snudda vid de artikulationer som visar på hur klass och åldersindelningar används för att göra skillnad mellan bra och dåliga mammor. En mer ingående analys av dessa aspekter vore intressant att utveckla vidare. Sammantaget ser vi att det sker ett diskursivt gränsdragande mellan rätt och fel, bra och dåligt i de politiska diskussionerna om assisterad befruktning även i de fall där den politiska viljan är att inkludera ensamstående kvinnor och utvidga ramarna för legitima familjer.

Denna slutsats kan jämföras med den som Edenheim (2005) dragit utifrån analysen av svenska statliga utredningar om avvikande kön och begär. Edenheim beskriver hur homosexuella endast kan erkännas "om homosexualiteten frånskrivs ett eget värde" och om de tillskrivs "en slags offerposition och endast med en uppvisad vilja att (efter)likna ett heterosexuellt samliv" (2005: 238). På ett liknande sätt framställs de ensamstående kvinnorna i det här materialet som drabbade av ett liv utan en man.

Att (hetero)repronormativitet präglar den svenska reproduktionspolitiska diskursen, trots en politisk vilja att inkludera ensamstående kvinnor, är tydligt i analysen. (Hetero)repronormativa utgångspunkter kommer särskilt till uttryck i fantasierna om de gränsöverskridande kvinnorna och om vikten av att tillskriva fadern och det manliga i samhället ett särskilt skyddsvärde. I den politiska debatten lämnas kärnfamiljen i det närmaste oproblematiserad och de brister som tidigare tillskrevs ensamstående mödrar förskjuts till vissa ensamstående mödrar - de som inte får sina barn på 'rätt' sätt.

\section{Noter}

1. Förutom assisterad befruktning för ensamstående föreslår också utskottet att regeringen ska tillsätta en utredning där "frågor om surrogatmoderskap ska prövas mer förutsättningslöst” (bet.

2011/12:SoU26: 1). Detta förslag röstades också igenom av riksdagen $\mathrm{i}$ samband med frågan om assisterad befruktning för ensamstående. Jag kommer dock inte att närmare studera politiken kring surrogatmoderskap i den här artikeln. Ytterligare en avgränsning som gjorts i artikeln är att diskutera enbart ensamstående kvinnor, om ett bredare material analyserats hade också politiska diskurser om ensamstående män blivit mer centrala.

2. Statens medicinsk-etiska råd (SMER) inrättades efter regeringsbeslut 1985 och har som uppgift att biträda beslutsfattare i medicinsk-etiska frågor. 
Rådet kan fungera som överremissinstans på förslag till lagändringar eller komma med egna råd om hur lagstiftning framöver kan komma att behöva förändras som svar på ny medicinsk utveckling (SMER odat:b). SMER har tidigare utrett frågor om assisterad befruktning på uppdrag av regeringen (Ds 2000:51: 17). Övergripande beskrivs rådets funktion som ett slags brygga mellan forskare och politiker. Liknande etiska råd finns runt om i Europa, men SMER är enligt egen utsaga unikt så till vida att det delvis består av politiskt valda företrädare (SMER odat:a).

\section{LITTERATUR}

- Andersson, Catrine (2011): Hundra år av tvasambet: Äktenskapet $i$ svenska statliga utredningar 1909-2009. Arkiv förlag, Lund

- Betänkande 2011/12:SoU26 Assisterad befruktning. Stockholm: Socialutskottet

- Carbin, Maria; Harjunen, Hannele \& Kvist, Elin (2011): (In)appropriate Mothers-Policy Discourses in Fertility Treatments for Lesbians in Denmark, Finland and Sweden, i: Judit Takács \& Roman Kuhar (eds.): Doing Families. Gay and Lesbian Family Practices. Peace institute, Institute for Contemporary Social and Political Studies, Ljubljana

- Correia, Helen \& Broderick, Pia (2009): Access to Reproductive Technologies by Single Women and Lesbians: Social Representations and Public Debate, i: Journal of Community os Applied Social Psychology 2009/19

. Cutas, Daniela \& Chan, Sarah (eds.) (2012): Families - Beyond the Nuclear Ideal. Bloomsbury, London

- Departementsserien 2000:51 Behandling av ofrivillig barnlöshet. Stockholm, Socialdepartementet

- Edenheim, Sara (2005): Begärets lagar: Moderna statliga utredningar och heteronormativitetens genealogi. Symposion, Lund

- Edenheim, Sara (2010): Politics out of Time Historical Expertise and Temporal Claims in Swedish Governmental Reports, i: Åsa Lundqvist \& Klaus Petersen (eds): In Experts We Trust: Knowledge, Politics and Bureaucracy in Nordic Welfare States. University Press of Southern Denmark, Odense

- Engwall, Kristina \& Peterson, Helen (red.) (2010): Frivillig barnlöshet: Barnfrihet $i$ en nordisk kontext. Serie framtider, Institutet för framtidsstudier. Dialogos förlag, Stockholm

. Franke, Katherine M. (2001): Theorizing Yes: An
Essay on Feminism, Law and Desire, i: Columbia Law Review 2001/181

. Glynos, Jason; Howarth, David; Norval, Aletta \& Speed, Ewen (2009): Discourse Analysis: Varieties and Methods. ESRC National Centre for Research Methods Review paper, National Centre for Research Methods NCRM/014. Hämtad ( 01/04 2013 ) på http://eprints.ncrm.ac.uk/796/1/discourse_analysis_NCRM_014.pdf

. Glynos, Jason \& Howarth, David (2007): Logics of Critical Explanation in Social and Political

Theory. Routledge, New York

. Graham, Susanna (2012): Choosing Single

Motherhood? Single women negotiating the nuclear family ideal, i: Daniela Cutas \& Sarah Chan (eds.): Families - Beyond the Nuclear Ideal.

Bloomsbury, London

. Halberstam, Judith (2007): Docksex och pingvinkärlek - Att göra det icke-mänskliga queer, i:

Tidskrift för genusvetenskap 2007/4

- Howarth, David (2000): Discourse. Open University Press, Buckingham

- Howarth, David \& Stavrakakis, Yannis (2000): Introducing Discourse Theory and Political Analysis, i: David Howarth, Aletta Norval \& Yannis Stavrakakis (eds.): Discourse Theory and Political Analysis: Identities, Hegemonies and Social Change. Manchester University Press, Manchester \& New York

- Jonsson Malm, Carolina (2011): Att plantera ett barn: Internationella adoptioner och assisterad befruktning i svensk reproduktionspolitik. Mediatryck, Lund

- Laclau, Ernesto (2005): On Populist Reason. Verso, London

- Liljestrand, Petra (1995): Legitimate State and Illegitimate Parents: Donor Insemination Politics in Sweden, i: Social Politics: International Studies in Gender, State \& Society 1995/3

- Lindgren, Cecilia (2006): En riktig familj: Adoption, föräldraskap och barnets bästa 1917-1975.

Carlsson bokförlag, Stockholm

· Lüttichau, Ingrid (2004): "We are Family": The Regulation of "Female Only" Reproduction, i: Social and Legal Studies 2004/1

- Motion 2010/111:Sf13 av Gunvor G Ericson och Magnus Ehrencrona (MP)

- Motion 2011/12:C391, Barbro Westerholm (FP)

- Motion 2011/12:So242 av Gunvor G Ericson, Ulf Holm, Mats Pertoft och Maria Ferm (MP)

- Motion 2011/12:So248 av Hillevi Larsson (S)

- Motion 2011/12:So462 av Marianne Berg, Bengt Berg, Eva Olofsson, Mia Sydow Mölleby, Amineh Kakabaveh och Lena Olsson (V) - Motion 2011/12:So472 av Kerstin Engle (S). 
- Motion 2011/12:So481 av Jenny Peterson och Camilla Waltersson Grönvall (MP)

- Motion 2011/12:So521 av Lena Hallengren, Christer Engelhardt, Lennart Axelsson, Gunnar Sandberg, Ann Arleklo, Catharina Bråkenhielm och Teres Lindberg $(\mathrm{S})$

- Motion 2011/12:So592 av Börje Vestlund, Fredrik Lundh Sammeli, Hans Ekström och Jonas Gunnarsson (S)

- Motion 2011/12:So596 av Marie Nordén och Carina Ohlsson $(S)$

- Motion 2011/12:So667 av Maria Abrahamsson och Olof Lavesson $(\mathrm{M})$

- Nordqvist, Petra (2006): Önskat och oönskat föräldraskap - kön och sexualitet i svensk lagstiftningshistoria om insemination, $i$ : Lambda Nordica 2006/1-2

- Proposition 2004/05:137 Assisterad befruktning och föräldraskap

- Riksdagens protokoll 2011/12:91. Assisterad befruktning. (29 mars 2012)
- Statens medicinsk-etiska råd (2013): Assisterad befruktning - etiska aspekter. SMER 2013:1. Stockholm

- Statens medicinsk-etiska råd (SMER odat.a): $O m$ Smer. Hämtad (13/5 2013)på

http://www.smer.se/om-smer/

- Statens medicinsk-etiska råd (SMER odat.b):

Uppdrag. Hämtad (13/5 2013) på

http://www.smer.se/om-smer/uppdrag/

- Stavrakakis, Yannis (1999): Lacan \& the Political.

Routledge, London/New York

- Stavrakakis, Yannis (2007): The Lacanian Left:

Psychoanalysis, Theory, Politics. Edinburgh

University Press, Edinburgh

. SOU 1953:9 Förslag till lagstiftning om insemination. Angivet av sakkunniga inom justitiedepartementet. Justitiedepartementet. Stockholm . Žižek, Slavoj (2001). Ideologins Sublima Objekt.

Glänta, Stockholm 